\title{
Investor Competence and Decision Familiarity Bias Analysis for Portfolio Diversification
}

\author{
Sherly Aprian Nurcahya ${ }^{1}$, Satia Nur Maharani ${ }^{2}$ \\ Department of Accounting, Faculty of Economics, State University of Malang ${ }^{1,2}$ \\ \{sherlyapriann@gmail.com\}
}

\begin{abstract}
Investor's decision to maximize returns and reduce investment risk is to diversify their portfolios. According to the Behavioral Finance study, the investment decision is influenced by emotional psychology. Therefore, this study aims to examine psychological factors, that is investor competence and familiarity bias towards the decision of individual investor portfolio diversification. Data were collected using a questionnaire for active investors in Malang, Surabaya and Jakarta. Research questionnaire were distributed in person or online. The results showed that the competence investors has a positive and significant effect on the decision of investor portfolio diversification. Meanwhile, familiarity bias has a significant negative effect on investor portfolio diversification decision. This reflects that investment decisions in trading are influenced by limited rationality, emotional factors, and individual personality traits. Whereas in conditions of economic and financial uncertainty, its is believed that humans cannot escape the aspects of psychological bias in the decision-making process.
\end{abstract}

Keywords: Behavioral Finance, Competence Effect, Familiarity Bias, Portfolio Diversification

\section{Introduction}

Based on modern portfolio theory by Harry Markowitz (1952), investors are advised not to invest only in one security, but to spread their investment in several securities, thus it is necessary for investors to form a portfolio through a combination of a number of stocks to minimize risk without reducing the expected return. This is confirmed by the statement of Oyenubi (2019) that increasing the number of shares in the portfolio can increase the level of diversification and have an impact on reducing portfolio risk.

Previous study of Bradfield and Munro (2017) found that it takes 15 to 30 stocks to effectively reduce the risk of $90 \%-95 \%$ in an investor's portfolio. This is evidence of the importance of portfolio diversification for investors, where the composition of the number of stocks that make up the portfolio reduces risk to a certain point. However, empirical evidence shows that most individual investors do not have optimal portfolios. Frensidy (2016) states that most investors in Indonesia do not diversify where most investors only own 4 to 5 shares with an average ownership of only 2 shares. 
In line with this, modern portfolio theory analyzes investor decisions based on the assumption between market efficiency and individual rationality by performing a comparative analysis of a number of event variables. Investors' decisions are considered rational based on an analysis of the availability of information (Fama, 1970; Shiller, 1999; Milan and Eid Jr., 2017). Meanwhile, Paola et. al (2017) provides a different view by analyzing the effect of individual behavior bias on stock trading performance. His study found that investment decisions in trading are influenced by limited rationality, emotional factors, and individual personality traits. This is confirmed by Kahneman and Tversky (1979) stated that the psychological aspect influences investors to allocate their income in high-risk investments and underdiversified portfolios. Investment decisions based on the influence of psychological factors that arise in the financial behavior of investors are the emergence of bias in the perception of the investment to be taken.

Graham et. al (2009) stated that investor competence (competence effect) is one of the psychological factors that can influence investment decision making. Competence effect is the willingness to act based on self-assessment in certain areas that depend on the subjective competence of the individual so that individuals feel skilled or knowledgeable in their field. In addition to investor competence, the psychological factor of familiarity has received attention in the last two decades, where a lot of evidence shows the impact of familiarity on investment decisions made by individuals (De Vries et al., 2017). Familiarity bias is the tendency of individual investors to invest in company stocks that are familiar to investors (Huberman, 2001).

Based on this background, this study seeks to examine psychological factors that are thought to influence portfolio diversification decisions. This study is different from previous research, namely using the competence effect and familiarity bias to test their effect on portfolio diversification decisions. So that the formulation of the problem can be drawn as follows: (1) Does the competence of investors affect the decision to diversify the investor's portfolio? (2) Does familiarity bias affect investors' portfolio diversification decisions?

\section{Literature Review and Hypothesis Development}

Debate arises among researchers regarding the consistency of Efficient Market Hypothesis when this theory is unable to explain anomalies in the phenomenon of money markets and capital markets. This anomaly in financial phenomena provides room for the view that Efficient Market Hypothesis fails to explain market behavior. Behavioral Finance strives to answer financial phenomena that the previous theory cannot explain. Taking a psychological point of view, Behavioral Finance seeks to explain the emotional or psychological patterns of investors in analyzing information and making decisions. To Macedo et. al (2011) states that anomalies are evidence of incorrect asset pricing by the market. Thus, Behavioral Finance emerged as a branch of social psychology that captures the human side of decision making (Kapoor \& Prosad, 2017). Behavioral Finance according to Litner (1998) is a study of how individuals interpret and behave towards information in making investment decisions. Economic and psychological literature documents many patterns of investor deviance from rational attitudes characterized by the emergence of various types of behavioral bias (Paola et. al, 2017). 


\subsection{The Influence of Investor Competence on Portfolio Diversification Decisions}

Graham et. al (2009) states that one of the psychological factors that can influence investors' decisions is competence (competence effect). Heath and Tversky (1991) proposed the competence effect as a person's willingness to act based on their own judgment in a particular area depending on the individual's subjective competence, namely whether the individual felt skilled or knowledgeable in his field. In financial markets where the subjective probability distribution of investors is uncertain, psychological factors such as the competence effect play an important role in decision making.

The competence of individual investors in the financial market reflects the existence of investor financial literacy, meaning that investors 'knowledge and understanding of working conditions on the financial market will have an impact on investors' decisions based on expected returns and investment risks. Graham, et. al. (2009) stated that investors who believe they are more skilled and knowledgeable in making financial decisions will act on their judgment. This statement was confirmed by Cohen and Kudryavtsev (2012) who stated that investors' decisions can be influenced by knowledge, historical performance, experience, and motivation.

The competency factor is one of the psychological factors studied by Chandra (2009) where the level of individual competence can influence investors' strategies and decisions in trading stocks. Investors with a high level of competence rely on their knowledge in valuing stocks to get an optimal portfolio. Furthermore, Graham, et. al. (2009) stated in their article that the better the competence of investors, the smarter they are in forming a diversified portfolio. Therefore, it can be concluded that the competence of investors affects portfolio diversification. H1: Investor Competence Has a Positive Effect on Investor Portfolio Diversification Decisions.

\subsection{The Influence of Familiarity Bias on Portfolio Diversification Decision}

Familiarity bias has been of particular concern to researchers in psychology and behavioral finance. De Vries, et. al (2017) argues that familiarity bias appears to be the dominant factor in explaining investor irrational behavior. Familiarity bias is a behavior where investors tend to judge something they already know is much better than something new. This behavior can be attributed to the assumption that investors are more comfortable with companies that are well known or heard of frequently. In addition, investors tend to prefer investing in domestic securities, often referred to as home bias. Investors feel more optimistic about the domestic market compared to the international market (Ackert and Deaves, 2010).

These reasons provide evidence that investors who invest based on familiarity bias often ignore the principles of portfolio theory (Huberman, 2001). According to Boyle et. al (2012), investors tend to have a number of investments in only a few stocks that they are only familiar with, instead of holding a diversified portfolio. Familiarity bias also encourages retail investors to make investment decisions based on brand recognition. Based on research conducted by De Vries et. al (2017) who examined familiarity bias towards investors' investment decisions in South Africa, familiarity bias also encourages individual investors to invest in companies with well-known brands. H2: Familiarity Bias has a negative effect on investors' portfolio diversification decisions. 


\section{Metodology}

This research uses a quantitative approach with an explanatory research type. The independent variables in this study are investor competence (X1) and familiarity bias (X2). While the dependent variable in this study is the portfolio diversification decision (Y). The population in this study were all investors in Malang, Surabaya and Jakarta. The sampling technique is a non-probability sample with the type of convenience sampling. Before the research instrument was distributed to the real respondents, the research instrument was carried out with face validity which showed whether the measuring device or research instrument in terms of apparently measured what you wanted to measure (Uma Sekaran \& Bougie, 2013). The face validity of this research was carried out by consulting the research instrument with the advisor. After doing face validity, then proceed with testing the validity using SPSS 25 with the product moment correlation formula developed by Pearson.

\section{Hypothesis Test}

\subsection{Determination Coefficient Test $\left(\mathbf{R}^{2}\right)$}

Table 1. Determination Coefficient Test Results

\begin{tabular}{ccccc}
\hline \multicolumn{5}{c}{ Model Summary } \\
\hline Model & R & R Square & Adjusted R Square & Std. Error of the Estimate \\
\hline 1 & $.635^{\text {a }}$ & .404 & .393 & 3.860 \\
\hline
\end{tabular}

Based on the table above, the result is $\mathrm{R}^{2}$ (R Square) of 0.404 or $40.4 \%$. This means that the diversity of portfolio diversification decision making is influenced by $40.4 \%$ of the independent variables, namely investor competence and familiarity bias, while $59.6 \%$ is influenced by other variables outside the variables studied.

\subsection{Partial Hypothesis Test ( $t$ test)}

Table 2. Partial Hypothesis Test ( $t$ test)

\begin{tabular}{ccccc}
\hline Independent Variable & $\mathbf{T}_{\text {value }}$ & Sig. & $\mathbf{t}_{\text {table }}$ & Explanation \\
\hline Investor Competence & 4,954 & 0,000 & 1,981 & Significant \\
Familiarity Bias & $-3,438$ & 0,001 & 1,981 & Significant \\
\hline
\end{tabular}

Based on the table above, it can be analyzed the effect of the independent variable partially on the dependent variable as follows:

\section{a) The Influence of Investor Competence on Investor Portfolio Diversification Decisions}

Based on the results of the regression analysis in the table above, it is known that the value of $\mathrm{t}_{\text {value }}>\mathrm{t}_{\text {table }}$ or $4.954>1.981$ and sig. $\mathrm{t}<0.05$ or $0.000<0.050$. This means that the investor competency variable has a positive and significant effect on the investor's portfolio diversification decision. So, it can be concluded that the first hypothesis is accepted. From these results, it can be seen that competence increases the ability of investors to analyze information related to portfolio diversification. So that, a good level of investor competence can affect the diversification of the investor's portfolio by producing an investment portfolio that maximizes utility. Investor competence in the stock market that reflects financial 
understanding that understands investors about how financial markets work. The results of this study support the research conducted by Graham et. al (2009) which states that when investors tend to feel competent, investors will act according to their orders in making decisions, so that investors who feel more competent will have a diversified portfolio than investors who feel they are less competent.

Van Rooij, et. al (2011) explained that financial literacy affects financial decisions, which is individuals with low financial knowledge tend to reduce stock investment. In general, an investor's educational status can show how much financial literacy an investor has. This is confirmed by the results of this study which show that most investors are dominated by investors with a bachelor's degree. According to Chandra (2009) investors with a higher education background tend to make decisions more frequently in stock trading activities by relying on their knowledge. Thus, the knowledge of investing that is owned by investors makes investors more confident in making investment decisions and more willing to take risks.

Investment decision making is strongly influenced by investors' understanding of market conditions because it reflects the price movements of securities as well as issues that are developing in the market that can affect investors in analyzing information. This concept describes the ability of investors to collect relevant information, plan, and understand events that affect financial decisions, including those related to the global economy (Abreu \& Mendes, 2010). Thus, investors who have knowledge of market conditions can properly collecting available information and see opportunities to make investment decisions.

Other supporting indicators of competence are traits or psychological characteristics and consistent responses to situations or information (Chouhan \& Srivastava, 2014). The statement "Considering stock price changes carefully" has the highest average representing indicators of traits. This statement has a positive meaning, so the greater of value that given by the respondent, that means respondents are more agree that traits support the level of investor competence which influences the decision-making process. Investors' prudence in managing information before making decisions is very important to help investors predict what will happen in the future. This is confirmed by Arnold's (2018) statement that prudence is needed to evaluate stocks and assess them based on projections.

In addition to traits, self-concept is also one of the supporting indicators for individual competency levels. Chouhan \& Srivastava (2014) define self-concept refers to individual attitudes, values, and self-image, for example is a person's belief that he or she can be successful in a given situation. This is supported by the questionnaire statement item, namely "Believing in the ability and knowledge of the stock market can improve market performance." This statement has a positive meaning, so the greater of value that given by the respondent, is the more agree that the nature (own concept) supports the competency level of investors who influence the decision-making process. Investors who believe in their abilities and knowledge can improve their performance in investing in the capital market. This is confirmed by Hendiana (2014) who states that self-confidence in one's abilities can affect the level of achievement and individual performance. In making investment decisions, investor confidence can affect the trading frequency of investors' shares. Investors who are confident will often trade stocks, so they will have more variety of shares in their portfolios(Tanusdjaja, 2018).

The last indicator that supports the level of investor competence is the investment motivation (motive) of each investor. In general, investment motivation is based on obtaining investment returns from the funds invested, so that a competent investor will set a target for the expected investment return. This is supported by the questionnaire statement which has the 
highest average representing the indicator of motivation, that is "Setting the target for the benefits obtained in investing." The profit target set by the investor represents the investment objective or motivation, so that investors will be more careful in making investment decisions by considering the existing factors and still paying attention to the principle of "high risk high return". Manik (2017) states that the key to choosing an optimal investment portfolio is how the ability of investors to measure the level of risk and the level of profit received. Thus, the ability to estimate the expected return in an investment is important and necessary for investors. The results of this study are in line with research conducted by Glaser and Weber and Karlsson and Norden (2010) who argue that an investor who considers himself to have above average ability will be more active in conducting stock transactions. This means that investors who feel they have better abilities than other investors have confidence in making decisions and are more willing to take risks.

\section{b) The Influence of Familiarity Bias on Investor Portfolio Diversification Decisions}

The familiarity bias variable in the previous table shows that the value of $t_{\text {value }}>t_{\text {table }}$ or $3.438>1.981$ and the value of sig. $t<0.05$ or $0.001<0.05$, which means that the familiarity bias variable has a negative and significant effect on investors' portfolio diversification decisions. So, it can be concluded that the second hypothesis is accepted. From these results, it can be seen that the familiarity bias psychological factor experienced by investors will have an impact on the lack of ability of investors to analyze available financial information, because investors who are under familiarity bias psychology will tend to choose stocks that are familiar to them. Thus, the greater the familiarity bias will affect the individual decisionmaking process which is limited to certain stocks and can lead to less than optimal diversification of the investment portfolio. The negative effect of familiarity bias in this study supports the applicability of behavioral finance theory, which is familiarity bias causes individuals not to fully analyze information and deviates from rationality in decision making. This is evidence that familiarity bias behavior can influence investors to make investment decision-making processes, which investors will tend to choose something that is already known or familiar.

Ellsberg (1961) in Tanaka, et. al (2015) states that ambiguity aversion is a condition in which individuals tend to like something that is known rather than something that is not yet known. Individuals with ambiguity aversion will tend to avoid something that is not clear, so they will choose something that is already known or familiar to them (Du \& Shelley, 2014). In the process of making investment decisions, investors will often be faced with uncertain market conditions, so that investors will avoid stocks that have never been known before. This is reinforced by the statement in the questionnaire which has the highest average, that is "In conditions of uncertainty, I tend to buy familiar stocks". This familiarity bias can occur because in uncertain conditions, investors tend to feel safer investing in familiar stocks. This is supported by Speidell's (2009) statement which explains that familiarity bias is an individual's tendency to look for things that make them feel comfortable. In addition, Wang et. al (2011) states that familiarity bias can affect the perception of investment risk by investors. In the same condition, investors will be more willing to speculate when they understand the situation and tend to choose stocks with risks that are known with certainty rather than those that are uncertain. This is confirmed by the statement of Chew et. al (2011) that the preference of investors to bet on known or more familiar risks is higher than betting on unknown or less familiar risks. 
Familiarity bias psychological factors also affect investors in making investment decisions based on brand recognition. Chira et. al (2011) stated that individuals tend to make choices based on their familiarity with brands. This is also reinforced by the statement on the research questionnaire, that is "I tend to buy shares in companies that have products that are widely known to the public". This behavior perceives investors' closeness to a certain brand as a benchmark for making investment decisions, so that investors will be limited to stocks with product brands that they only know about. Investors with familiarity bias tend to give greater weight to the shares of companies with familiar products than companies with unfamiliar products, without further analyzing the available information. This is in line with research by De Vries et. al (2017) where familiarity bias encourages individual investors to invest in companies with well-known product brands. In large institutions, share ownership is negatively related to brand recognition and not associated with brand quality. However, it is different from retail investors who have a positive relationship with brand recognition that is consistent with comfort seeking and familiarity (Ackert and Deaves, 2010).

The existence of professional or geographical proximity is also one of the reasons for the emergence of familiarity bias behavior in investment decisions (Huberman, 2001). Professional or geographic proximity, which indicates that investors tend to invest in domestic companies. This is supported by the questionnaire statement "I consider it safer to invest in the domestic market than in the international market". In this case, investors tend to prefer and feel safe investing in domestic securities or often referred to as home bias. The existence of home bias can lead to less than optimal portfolios owned by investors, so that the profits obtained are not optimal. Grinblatt and Koleharju (2001) say that familiarity bias is also supported by language differences and institutional barriers. In research conducted in Finland, which has two official languages, namely Finnish and Swedish, Finnish investors tend to invest in companies that publish financial reports in Finnish. In other words, the existence of language differences and institutional barriers is also the reason investors consider the international capital market to be less attractive than the domestic capital market.

In addition, the familiarity bias behavior makes investors think that company stocks in the domestic capital market have better performance than the international capital market. The questionnaire statement "Stocks on the domestic capital market perform better than stocks on the international capital market," supports this statement. Investors with familiarity bias will tend to look for information that supports stocks they know in the domestic market. In this condition, investors tend to make biased decisions with a heuristic pattern due to limited time and information (Onsomu, 2014). Thus, investors with familiarity bias will be limited by information only on domestic market conditions. This is evidence that familiarity bias causes investors to ignore the principles of portfolio theory in investing and be more optimistic about the domestic capital market than the international capital market.

\section{Conclussion}

Based on the results of the $t$ test that has been carried out, the following conclusions can be drawn:

a) Investor competence (competence effect) has a significant positive effect on investors' portfolio diversification decisions. This causes investors to make investment decisions based on their judgment, so as to produce optimally diversified portfolios.

b) Familiarity bias has a significant negative effect on investors' portfolio diversification decisions. Familiarity bias causes investors to tend to have limited investment options in 
stocks, that is, only shares of familiar companies. This can lead to investors having a less diversified portfolio.

\section{References}

[1] Ackert, L. F. and R. Deaves. 2010. Behavioral Finance: Psychology, Decision-Making, and Markets. Mason, USA: South-Western College Pub.

[2] Abreu, M., \& Mendes, V. (2010). Financial literacy and portfolio diversification. Quantitative Finance. https://doi.org/10.1080/14697680902878105

[3] Arnold, G. 2018. The Great Investors. Jakarta: PT Gramedia

[4] Boyle, P., Garlappi, L., Uppal, R., \& Wang, T. (2012). Keynes meets Markowitz: The trade-off between familiarity and diversification. Management Science. https://doi.org/10.1287/mnsc.1110.1349

[5] Bradfield, D., \& Munro, B. (2017). The number of stocks required for effective portfolio diversification: the South African case. South African Journal of Accounting Research. https://doi.org/10.1080/10291954.2015.1122284

[6] Chandra, A. (2009). Individual Investor Trading Behavior and The Competence Effect. Jorunal of Behavioral Finance. Vol.6, pg. 56-70.

[7] Chew, S. H., Ebstein, R. P., \& Zhong, S. (2011). Ambiguity Aversion and Familiarity Bias: Evidence from Behavioral and Gene Association Studies. J Risk Uncertain. DOI 10.1007/s11166-011-9134-0

[8] Chira, I., Adams, M., \& Thornton, B. (2011). Behavioral Bias Within The Decision Making Process. Journal of Business \& Economics Research (JBER). https://doi.org/10.19030/jber.v6i8.2456

[9] Chouhan, V. S., \& Srivastava, S. (2014). Understanding Competencies and Competency Modeling - A Literature Survey. IOSR Journal of Business and Management. https://doi.org/10.9790/487x-16111422

[10] Cohen, G., \& Kudryavtsev, A. (2012). Investor rationality and financial decisions. Journal of Behavioral Finance. https://doi.org/10.1080/15427560.2012.653020

[11] De Vries, A., Erasmus, P. D., \& Gerber, C. (2017). The familiar versus the unfamiliar: Familiarity bias amongst individual investors. Acta Commercii. https://doi.org/10.4102/ac.v17i1.366

[12] Du, N., \& Shelley, M. K. (2014). Exploring Ambiguity and Familiarity Effects in The "Earnings Game" Between Managers and Investors. Journal of Behavioral Finance. https://doi.org/10.1080/15427560.2014.877015

[13] Frensidy, B. (2016). The performance of undiversified portfolio in Indonesia stock exchange. Journal of Applied Business Research. https://doi.org/10.19030/jabr.v32i4.9720

[14] Glaser, M. \& Weeber, M. (2005). Overconfidence and Trading Volume.

[15] Graham, J. R., Harvey, C. R., \& Huang, H. (2009). Investor competence, trading frequency, and home bias. Management Science. https://doi.org/10.1287/mnsc.1090.1009

[16] Grinblatt, M., \& Keloharju, M. (2001). How distance, language, and culture influence stockholdings and trades. Journal of Finance. https://doi.org/10.1111/0022-1082.00355

[17] Heath, C., \& Tversky, A. (1991). Preference and belief: Ambiguity and competence in choice under uncertainty. Journal of Risk and Uncertainty. https://doi.org/10.1007/BF00057884 
[18] Hendriana, H. (2014). Build students' self-confidence through humanist mathematics learning. MIPA Teaching Journal,19(1), 52-60.

[19] Huberman, G. (2001). Familiarity breeds investment. Review of Financial Studies. https://doi.org/10.1093/rfs/14.3.659

[20] Kahneman, D., \& Tversky, A. (1979). Prospect Theory: An Analysis of Decision under Risk Daniel Kahneman; Amos Tversky. Econometrica.

[21] Kapoor, S., \& Prosad, J. M. (2017). Behavioural Finance: A Review. Procedia Computer Science. https://doi.org/10.1016/j.procs.2017.11.340

[22] Karlsson, A. \& Norden, L. 2009. Investor Competence, Information, and Investment Activity. Department of Corporate Finance, School of Business, Stockholm University

[23] Lintner, A. G., (1998). Behavioral Finance: Why Investors Make Bad Decisions. Yanni-Bilkey Investment Consulting

[24] Manajemen Komputer, P., \& Kaputama Binjai, S. (2017). ANALISIS DIVERSIFIKASI PORTOFOLIO YANG OPTIMAL DENGAN MENGGUNAKAN METODE MULTI AGENT DAN BAYESIAN NETWORK Fuzy Yustika Manik. JIK (Jurnal Informatika Kaputama).

[25] Markowitz, H. (1952). Portfolio Selection. The Journal of Finance. https://doi.org/10.2307/2975974

[26] Milan, P. L. A. B \& Eid Jr, W. (2017). Investment Portfolios in an Emerging Economy: What Drives Portfolio's Diversification?. Emerging Markets Journal, Vol.7, No.1

[27] Onsomu, N. Z. (2014). The impact of behavioral biases on investor decisions in Kenya: male vs female. International Journal of Research in Humanities, Arts and Literature.

[28] Oyenubi, A. (2019). Diversification Measures and the Optimal Number of Stocks in a Portfolio: An Information Theoretic Explanation. Computational Economics. https://doi.org/10.1007/s10614-016-9600-5

[29] Pendleton, A. \& Robinson, A. 2018. Lack of Diversification Among Employee Stock Owners: An Empirical Evaluation of Behavioral Explanation. Human Resourch Management, 1-13.

[30] Paola, M. D., Giola, F. \& Piluso, F. 2017. Does Reminding of Behavioral Biases Increas Returns from Financial Trading? A Field Experiment. Institute of Labor Economics: Discussion Paper Series, No. 10983.

[31] Prosad, J. M \& Kapoor, S. 2015. Theory of Behavioral Finance. Volume in the Advances in Finance, Accounting, and Economics (AFAE).

[32] Speidell, L. S. (2009). Investing in the Unknown and the Unknowable-Behavioral Finance in Frontier Markets. Journal of Behavioral Finance. https://doi.org/10.1080/15427560902719323

[33] Tanaka, Y., Fujino, J., Ideno, T., Okubo, S., Takemura, K., Miyata, J., Kawada, R., Fujimoto, S., Kubota, M., Sasamoto, A., Hirose, K., Takeuchi, H., Fukuyama, H., Murai, T., \& Takahashi, H. (2015). Are ambiguity aversion and ambiguity intolerance identical? A neuroeconomics investigation. Frontiers in Psychology. https://doi.org/10.3389/fpsyg.2015.01550

[34] Tanusdjaja, H. (2018). KEPUTUSAN INVESTASI INVESTOR INDIVIDU BERDASARKAN KOMPETENSI, OVERCONFIDENCE, DAN PENDIDIKAN. Jurnal Muara Ilmu Ekonomi Dan Bisnis. https://doi.org/10.24912/jmieb.v2i1.998

[35] Uma Sekaran \& Bougie. (2013). Research Method for Business: A skill Building Approach, 6th edition.Wiley\&Son Ltd. In United States: John Wiley \& Sons Inc.

[36] van Rooij, M., Lusardi, A., \& Alessie, R. (2011). Financial literacy and stock market participation. Journal of Financial Economics. 
https://doi.org/10.1016/j.jfineco.2011.03.006

[37] Wang, M., Keller, C., \& Siegrist, M. (2011). The less you know, the more you are afraid of-A survey on risk perceptions of investment products. Journal of Behavioral Finance. https://doi.org/10.1080/15427560.2011.548760 